\title{
SNAKE ANTIVENOMS: ADVERSE REACTIONS AND PRODUCTION TECHNOLOGY
}

\author{
Morais VM (1), Massaldi H (1)
}

(1) Department of Biotechnological Development and Production, Hygiene Institute, School of Medicine, Universidad de la República, Montevideo, Uruguay.

\begin{abstract}
Antivenoms have been widely used for more than a century for treating snakebites and other accidents with poisonous animals. Despite their efficacy, the use of heterologous antivenoms involves the possibility of adverse reactions due to activation of the immune system. In this paper, alternatives for antivenom production already in use were evaluated in light of their ability to minimize the occurrence of adverse reactions. These effects were classified according to their molecular mechanism as: anaphylactic reactions mediated by $\operatorname{lgE}$, anaphylactoid reactions caused by complement system activation, and pyrogenic reactions produced mainly by the presence of endotoxins in the final product. In the future, antivenoms may be replaced by humanized antibodies, specific neutralizing compounds or vaccination. Meanwhile, improvements in antivenom quality will be focused on the obtainment of a more purified and specific product in compliance with good manufacturing practices and at an affordable cost.
\end{abstract}

KEY WORDS: snake antivenom, anaphylactic reaction, complement system activation, endotoxins.

CONFLICTS OF INTEREST: There is no conflict.

\section{CORRESPONDENCE TO:}

VICTOR MORAIS, Departamento de Desarrollo Biotecnológico y Producción, Instituto de Higiene, Av. Alfredo Navarro 3051, 11300, Facultad de Medicina, Universidad de la República, Montevideo, Uruguay. Phone: 5982487 1288, ext. 1044. Email: vmorais@higiene.edu.uy. 


\section{INTRODUCTION}

Antivenoms have been used successfully for more than a century and up to now constitute the only effective treatment for snakebites and envenomations by other poisonous animals (1-6). Unfortunately, these products are composed of antibodies from immunized animals; hence, the use of heterologous proteins for human treatment involves the possibility of adverse reactions due to activation of the immune system. Unfavorable effects may range from mild symptoms like chills, nausea and fever, to serious problems such as bronchospasms and anaphylactic shock, even when the most refined antivenoms are administered (7-9).

Technologies for snake antivenom production vary according to the production laboratory, even in the same country. Classically, protocols that yield the $F\left(a b^{\prime}\right)_{2}$ fragment, based on pepsin digestion followed by ammonium sulfate fractionation (10) have been used worldwide. More recently, a caprylic acid purification process has been adopted by some countries, including Costa Rica $(11,12)$ and Thailand (13), while a chromatographic process alone has become the norm in other regions, like Europe and the United States $(7,8,14)$. The $\mathrm{F}\left(\mathrm{ab}^{\prime}\right)_{2}$ product is preferred in Brazil $(11$, 15), Argentina, Mexico and also in India (16). Whole immunoglobulin antivenoms are used in some countries like Costa Rica, generally associated with the caprylic acid or ammonium sulfate processes. A product based on the Fab fragment is also used in the United States version of the antivenom $(7,8)$.

In the present study we discuss the possible mechanisms that trigger these side reactions and the possibilities that antivenom-producing laboratories have to minimize or control these difficulties through processing alternatives.

\section{TYPE I HYPERSENSITIVITY (IMMEDIATE HYPERSENSITIVITY, ANAPHYLACTIC REACTION)}

This is an early adverse reaction mediated by $\lg E$ antibodies, reactive to specific antigens, that are attached to basophil or mast cell Fc receptors (FceR). The crosslinking of the cell-bound IgE antibodies by the antigen induces degranulation and determines the release of histamine and other pharmacological mediators that lead to several actions including increased vascular permeability, vasodilatation, bronchial and visceral smooth-muscle contraction, mucous secretion and local inflammation (17-19). The systemic presence of antigens, like those existing in heterologous antivenoms, can generate anaphylactic shock. It is an immediate 
hypersensitivity reaction characterized by edema in several tissues and drop in blood pressure, secondary to vasodilatation (18). This response usually occurs in atopic subjects previously sensitized by some antivenom component.

Although the probability of anaphylaxis depends on the patient's sensitivity, the production laboratory can implement various processing alternatives to minimize the occurrence of this adverse reaction. The presence of impurities in antivenoms increases the possibility of anaphylactic shock due to $\lg E$ antibodies against these subtances (mainly other heterologous animal proteins), especially in atopic individuals. Sera incorrectly purified, or with excessive total protein load, can contribute to the development of this reaction.

Purification of immunoglobulins by caprylic acid precipitation of non-IgG plasma proteins, presently offers a cost-effective alternative, which some laboratories have already adopted or are developing $(12,20)$. The method fabricates a product with a relatively high purity in one step, which makes it suitable as a standalone process, or as the initial step of a purification chain $(12,21)$. Furthermore, caprylic acid purification reveals a high quality-cost ratio, making it suitable for most countries, even the poorest ones $(20,22)$. If major expenses are permitted, the use of affinity and ionic exchange columns to purify the final product may be convenient and in fact, it has been proposed to improve its purity $(13,23)$. Purification by chromatographic techniques alone has already been proposed $(14,24)$, but with the drawback of a substantially higher cost (25).

The utilization of more specific antibodies reduces the amount of total protein injected into the patient, thereby reducing the probability of anaphylactic shock, so that improvements in immunization schedules and procedures are important to obtain plasma with higher activity per protein unit (specific activity) $(24,26,27)$. Several groups have been seeking alternative methods to prepare toxoids through venom detoxification, which would maintain its immunogenicity and minimize the damage to serum-producing animals $(28,29)$. In the processing field, several authors have proposed the use of affinity chromatography to purify only neutralizing antibodies (30) or IgG isotypes with better neutralizing potency, like horse $\operatorname{Ig} G(T)(14,31-34)$. In both cases the total amount of protein injected into the patient would decrease, without losing the required potency.

For more than 100 years, horses have been the animal of choice for production of antivenom and other antisera $(4,5,10,35-37)$. Therefore, many patients are 
presently sensitive to horse proteins and at risk for anaphylactic reaction after a second contact. Moreover, horse $\lg G(T)$ is highly glycosylated and more immunogenic than other antibody isotypes $(2,38)$. For patients known to be sensitive to equine proteins, avoidance of antivenoms prepared in this manner is mandatory and should reduce the incidence of anaphylactic shocks. Some production laboratories are now successfully using other animals like sheep as sources of sera $(7,28,39)$. Recent studies indicate the use of camels for antivenom production, due to lower in vitro complement activation than found in horses and sheep $(40,41)$. It would be an appropriate option for countries where camels are available $(24,41)$. At this point, it is important to note that even when human antibodies are employed for treating other diseases, like intravenous immunoglobulins (IGIV), anaphylactic shock and other adverse reactions could still occur (42).

Snake venoms are a complex mixture of peptides, proteins and enzymes, some of which are responsible for their toxic effects. Therefore, several different types of antibodies are needed to neutralize these toxic substances. A promising future alternative for treatment with specific monoclonal or humanized antibodies is likely $(24,43-46)$. The production of humanized antibodies like single-chain Fv expressed in philamentous phage could replace heterologous antisera, thereby reducing the probability of adverse reaction (47). Studies identifying toxicity factors and the similarity among toxin structures allow the production of antibodies that confer cross neutralization and are a good starting point to develop monoclonal therapy and vaccines $(48,49)$. Several complex steps are required to develop an effective vaccine against snake venom including: the identification of toxins associated with damaging or even lethal effects from the mixture of peptides and proteins which constitutes snake venoms (50), the detoxification by either chemical or genetic means of vaccine production, the achievement of an effective and safe humoral immune response and, above all, the financial support to carry out all the necessary assays for vaccine development.

Other compounds may be used instead of neutralizing antibodies (51-53). Natural products from plants of different regions, some utilized for centuries in traditional medicine, have been studied (54). Chemical compounds from natural plants - like terpens, steroids and flavonoids - were assayed to determine the inhibition of lethality of Bothrops jararaca venom in mice. Although some of the compounds showed a degree of neutralizing activity, none reached $100 \%$ protection (55). 
Numerous investigations are designed to understand the innate resistance of some animals to snake venoms. Some compounds have been isolated from snakes, opposums and other animals with promising results (56-60). However, the use of substances other than immunoglobulins may not guarantee the absence of anaphylactic reactions. In these cases, the research is at the preclinical level, so results on adverse responses are still unavailable.

\section{COMPLEMENT SYSTEM ACTIVATION (CSA)}

Anaphylotoxins, namely C3a, C4a and C5a, are low-molecular-weight active peptides that are generated by complement system activation. They stem from C3, C4, C5 serum complement proteins and are created during complement fixation by $\mathrm{Ag}-\mathrm{Ab}$ complexes, immunoglobulin aggregates and others. The anaphylotoxins (mainly C5a and to a lesser extent $\mathrm{C} 3 \mathrm{a}$ and $\mathrm{C} 4 \mathrm{a}$ ) stimulate chemotaxis, neutrophil activation and degranulation of basophils and mast cells, with release of pharmacologically active mediators of immediate hypersensitivity $(61,62)$. The net effects of these activities are histamine- and leucotriene-mediated contraction of vascular smooth muscle, increased vascular permeability and migration of neutrophils and monocytes from blood vessels $(19,61,62)$.

\section{CSA by the Fragment Fc of Heterologous Antibody}

In the past, it was presupposed that the presence of Fc fragments in antivenoms was the only, or the most important, cause of anaphylotoxic reactions (63). However, a number of clinical trials have yielded controversial results about the efficacy of snake antivenoms constituted by $\mathrm{F}\left(\mathrm{ab}^{\prime}\right)_{2}$ and $\mathrm{Fab}(2,7,9,31)$. Additionally, clinical studies with whole IgG antibodies produced by caprylic acid purification revealed a relatively low incidence of early adverse reactions $(9,64)$. These conflicting results can be explained by the presence of variable aggregate levels in the product.

Recently, Otero et al. (65) reported a clinical trial that compared two antivenoms composed of IgG processed by caprylic acid purification, with similar aggregate concentration. One of which was treated with $\beta$-propiolactone, known to inhibit the complement activation (66). Although the $\beta$-propiolactone treated antivenom showed in vitro minor anticomplementary activity, no significant difference was found in the number of adverse reactions detected in patients. 


\section{CSA by Protein Aggregates}

The presence of protein aggregates can also provoke complement system activation. Such aggregates found in antivenoms are originated mainly in the immunoglobulin fraction during production. Aggressive treatments like pepsin digestion and low $\mathrm{pH}$ lead to immunoglobulin denaturation that, in turn, diminishes activity and augments aggregate levels (67-69). Given that the presence of Fc fragments has been questioned as an important cause of adverse reactions, pepsin digestion of immunoglobulins should be reconsidered as a necessary process step, due to the important increase of aggregate levels achieved. Despite this, if immunoglobulin digestion is desired, another step to eliminate aggregates should be included (68, 69).

Purification processes have also been implicated in aggregate formation. The second precipitation and resuspension steps that take place in the classic ammonium sulfate fractionation protocol for an $\lg \mathrm{g}$ or $\mathrm{F}\left(\mathrm{ab}^{\prime}\right)_{2}$ product (10), seem to increase the aggregates level when compared to caprylic acid purification, in which the immunoglobulins remain in a soluble form continuously $(12,22,24,64)$.

Another important cause of aggregate formation is long storage duration. The final product will lose activity if stored several years due to antibody denaturation, which, in turn, gives rise to an increased aggregate level. Storage temperature of antivenoms in liquid form is probably an important factor in antibody denaturation and increasing aggregate formation. Rojas et al. (70) found that antivenom storage at $20^{\circ} \mathrm{C}$ or more for a year increased the aggregate level as compared with $4^{\circ} \mathrm{C}$ storage. Furthermore, García et al. (63) found differences in the augmentation of aggregate levels among antivenoms stored for three years with different preservatives, meaning that these substances could accelerate the normal denaturation process.

\section{CSA by Immune Complexes (Type III Hypersensitivity)}

In 1905, Pirquet and Schick studied the side effects caused by the administration of large quantities of a foreign serum containing antitoxins, a technique used mainly for the treatment of diphtheria and tetanus. In particular, they stressed the fact that symptoms appeared more rapidly after a second exposure to the foreign serum than after the first administration. Their clinical descriptions included fever and rashes, and 
some reports of kidney damage with proteinuria, lymphadenopathy and joint symptoms (71).

Type III hypersensitivity is mediated by antigen-antibody complexes. As a consequence of antivenom administration, the patient's immune system reacts by producing antibodies that attach to foreign antibodies (antivenom), resulting in the formation of an immune complex. Such complexes can stimulate an acute inflammatory response that leads to complement activation and leukocyte infiltration, the so-called "serum sickness" syndrome.

This is a systemic late adverse reaction characterized by vasculitis, glomerulonephritis and arthritis due to intravascular formation and deposition of immune complexes that subsequently fix the complement and initiate the hypersensitivity reaction. Patients may develop fever, lymphadenopathy, urticaria and arthritis (19). The classic reaction, that occurs 7 to 15 days after the triggering injection, is known as the primary form of serum sickness. Similar manifestations that appear in a few days following the injection represent the accelerated form of serum sickness, which presumably occurs in subjects already sensitized.

To diminish the incidence of this reaction, it is important to reduce antivenom reactivity to the immune system. In this way, the solutions proposed above to attenuate type I anaphylactic reaction may be useful in this case as well. León et al. (72) showed that equine IgG induces a higher anti-immunoglobulin response in mice, in comparison to $F\left(a b^{\prime}\right)_{2}$. Nevertheless, the digestion process gives rise to an important activity loss through antibody denaturation so the amount of foreign protein present in a dose of $F\left(a b^{\prime}\right) 2$ antivenom should be larger than that in a whole IgGbased antivenom (67). Therefore, by considering that the total amount of heterologous protein administered plays a more determinant role in the occurrence of serum sickness than the type of antibody preparation utilized, it is doubtful to establish a priori which molecule induces less response (72). Alternatives including vaccination and the use of humanized antibodies or other neutralizing substances may be the best answer in a near future.

\section{PYROGENIC REACTIONS}

Antivenom contamination by endotoxins is the main cause of pyrogenic reactions in patients. Bacterial endotoxins consist of lipopolysaccharide, a major component of the outer cell membrane of gram-negative bacteria. Endotoxins present strong 
biological effects on humans and other mammals when reach their bloodstream during bacterial infection or via intravenous application of a contaminated medicine.

Endotoxins are known to cause fever at very low doses and septic shock at higher doses (73). The threshold level of endotoxin for intravenous applications is set to 5 endotoxin units (EU) per kilogram of body weight per hour. The term EU describes the biological activity of an endotoxin (74). The molecular mechanism of toxicity is not completely understood but it has been related to the interaction with TLR4 (Toll-like receptor 4) and/or LPB (LPS binding protein) receptors and to the activation of monocytes and other cell components of the immune system that carry out TNF and other cytokine production (75-79).

Higher levels of endotoxins are related to bacterial infection or digestive tract injuries, but contamination at low concentrations can be found in pharmaceutical products. Contamination of antivenom products with endotoxins take place if preventive measures are not followed during processing (80). The presence of low doses of endotoxins in antivenoms generate an important increase of mild, early adverse reactions (generally fever) in patients (9). To avoid endotoxins, the production laboratories must implement strict quality requirements in facilities, raw materials, process systems and equipment.

Endotoxins are very stable molecules of varying size; their biologically active part can survive extremes of temperature and $\mathrm{pH}$ in comparison to proteins. Temperatures from 180 to $250^{\circ} \mathrm{C}$ and acids or alkalis of at least $0.1 \mathrm{M}$ must be chosen to destroy endotoxins in laboratory equipment (74). Therefore, it represents a challenge to remove endotoxins from biological fluids including proteins. In addition to this, endotoxin shows a strong association with proteins, so steps that involve protein concentration also involve endotoxin concentration and steps that involve protein purification of other protein involve endotoxin elimination (81). Thus, ammonium sulfate fractionation process tends to increase endotoxin level more than the caprylic acid purification of immunoglobulins in a production system, not only because of a higher endotoxin level in the raw materials and a longer process time, but also due to a specific concentration of endotoxins in the final precipitate, which corresponds to the IgG fraction (81).

Finally, if a product is accidentally contaminated and fails to pass the quality control, it should be discarded or reprocessed. Decontamination is a costly alternative, so avoiding endotoxin contamination must be the preferred choice (74). However, in 
unexpected cases, it is absolutely necessary to count with a decontamination procedure in order to save a given production batch that otherwise would be discarded. With this goal, several systems including ultrafiltration membranes and chromatography resins coupled to different ligands have shown good capacity to capture and remove endotoxins $(73,74,82-84)$. Unfortunately, the use of these systems involve variable yield losses, so this is another reason why they should be applied only to save occasional production batches but not as routine (85).

\section{CONCLUDING REMARKS}

In the past century, antitoxic sera were widely used for diphtheria, tetanus and treatment of accidents with poisonous animals $(10,35-37,71)$. Nowadays, for tetanus and diphtheria treatments, the antitoxic sera have been replaced by vaccination, antibiotic therapy and human neutralizing antibodies, but for treating envenomation by snakes and others animals, heterologous antivenoms still remain the only effective solution.

Possibly in a near future, antivenoms will be replaced by vaccination and humanized antibodies or/and specific neutralizing compounds. Meanwhile the improvement in antivenom quality must focus on the increase of product purity and the reduction of aggregates, as well as on the implementation of good manufacturing practices (GMP). Unfortunately the incorporation of refined purification techniques to antivenom production process and others commercials factors have carried on an important cost increase, thereby causing an strong antivenom shortage specially in the poorest countries $(25,86-89)$. The best solution includes best quality antivenoms at an affordable cost $(20,22)$.

\section{REFERENCES}

1. Chippaux JP, Goyffon M. Venoms, antivenoms and inmunotherapy. Toxicon. 1998;36(6):823-46.

2. Theakston RDG, Warrell DA, Griffiths E. Report of a WHO workshop on the standardization and control of antivenoms. Toxicon. 2003;41(5):541-57.

3. Wilde $\mathrm{H}$, Thipkong $\mathrm{P}$, Sitprija V, Chaiyabutr $\mathrm{N}$. Heterologous antisera and antivenins are essential biologicals: perspectives on a worldwide crisis. Ann Intern Med. 1996;125(3):233-6. 
4. Calmette A. Contribution a l'etude du venin des serpents. Immunisation des animaux et traitement de l' envenimation. Ann Inst Pasteur. 1894;8:275-91.

5. Calmette A. Contribution à l'ètude des venins, des toxins et des serums antitoxiques. Ann Inst Pasteur. 1895;9:225-51.

6. Hawgood B. Doctor Albert Calmette 1863-1933: founder of antivenomous serotherapy and of antituberculous BCG vaccination. Toxicon. 1999;37(9):1241-58.

7. Clark RF, McKinney PE, Chase PB, Walter FG. Immediate and delayed allergic reactions to Crotalidae Polyvalent Immune Fab (ovine) antivenom. Ann Emerg Med. 2002;39(6):671-7.

8. Dart RC, Mcnally J. Efficacy, safety, and use of snake antivenoms in the United States. Ann Emerg Med. 2001;37(2):181-8.

9. Otero-Patino R, Cardozo J, Higashi H, Nuñez V, Diaz A, Toro M, García M, Sierra A, García LF, Moreno A, Medina M, Castañeda N, Silva-Diaz JF, Murcia M, Cardenas SY, Dias da Silva WD. A randomized, blinded, comparative trial of one pepsin-digested and two whole IgG antivenoms for Bothrops snake bites in Uraba, Colombia. The Regional Group of Antivenom Therapy Research (REGATHER). Am J Trop Med Hyg. 1998;58(2):183-9.

10. Harms AJ. The purification of antitoxic plasmas by enzyme treatment and heat denaturation. Biochem J. 1948;42(3):390-7.

11. Gutiérrez JM, Higashi HG, Wen FH, Burnouf T. Strengthening antivenom production in Central and South American public laboratories: Report of a workshop. Toxicon. 2007;49(1):30-5.

12. Rojas G, Jiménez JM, Gutierrez JM. Caprylic acid fractionation of hyperinmune horse plasma: description of a single procedure for antivenom production. Toxicon. 1994;32(3):351-63.

13. Raweerith $R$, Ratanabanangkoon K. Fractionation of equine antivenom using caprylic acid precipitation in combination with cationic ion-exchange chromatography. J Immunol Meth. 2003;282(1-2):63-72.

14. Pepin-Covatta S, Lutsch C, Grandgeorge M, Scherrmann JM. Immunoreactivity of a new generation of horse $\mathrm{F}(\mathrm{ab})_{2}$ preparations against European viper venoms and the tetanus toxin. Toxicon. 1997;35(3):411-22.

15. Raw I, Guidolin R, Higashi H, Kelen E. Antivenins in Brazil: preparation. In: Tu AT (editor). Handbook of natural toxins. Vol. 5. New York: Marcel Dekker; 1991. p.55783. 
16. Jadhav SS, Kapre SV. Antivenom producion in India. In: Tu AT (editor). Handbook of natural toxins. vol. 5. New York: Marcel Dekker; 1991, p. 584-608.

17. Abbas AK, Lichtman AH, Pober JS (editors). Cellular and molecular immunology. 4th ed. Philadelphia: WB Sanders Co.; 2000.

18. Abbas AK, Litchman AH. Immediate Hypersensitivity. In: Abbas AK, Litchman AH (editors). Cellular and molecular immunology. 5th ed. Philadelphia: Saunders Elsevier Science; 2003.

19. Cruce JM, Lewis RE. Types I, II, III, and IV hypersensitivity. In: Atlas of immunology. $2^{\text {nd }}$ ed. Florida: CRC Press; 2004.

20. Morais V, Massaldi $\mathrm{H}$. Economic evaluation of snake antivenom production in the public system. J Venom Anim Toxins incl Trop Dis. 2006;12(3):497-511.

21. Steinbuch $M$, Audran $R$. The isolation of IgG from mammalian sera with the aid of caprylic acid. Arch Biochem Biophys. 1969;134(2):279-84.

22. Gutiérrez JM, Rojas E, Quesada L, León G, Nuñez J, Laing GD, Sasa M, Renjifo JM, Nasidi A, Warrell DA, Theakston RDG, Rojas G. Pan-African polyspecific antivenom produced by caprylic acid purification of horse IgG: an alternative to the antivenom crisis in Africa. Trans R Soc Trop Med Hyg. 2005;99(6):468-75.

23. Saetang T, Treamwattana N, Suttijitpaisal P, Ratanabanangoon K. Quantitative comparison on the refinement of horse antivenom by salt fractionation and ionexchange chromatography. J Chromatog B. 1997;700(1-2):233-9.

24. Gutiérrez JM, Lomonte B, León G, Rucavado A, Chaves F, Angulo Y. Trends in snakebite envenomation therapy: Scientific, technological and Public Health considerations. Curr Pham Des. 2007;13(28):2935- 50.

25. Krifi MN, El Ayeb M. Dellagi K. The improvement and standardization of antivenom production in developing countries: comparing antivenom quality, therapeutical efficiency, and cost. J Venom Anim Toxins. 1999;5(2):128-41.

26. Chotwiwatthanakun C, Pratanaphon R, Akesowan S, Sriprapat S, Ratanabanangkoon K. Production of potent polyvalent antivenom against three elapid venoms using a low dose, low volume, multi-site immunization protocol. Toxicon. 2001;39(10):1487-94.

27. Sriprapat S, Aeksowan S, Sapsutthipas S, Chotwiwatthanakun C, Suttijitpaisal P, Pratanaphon R, Khow O, Sitprija V, Ratanabanangkoon K. The impact of a low dose, low volume, multi-site immunization on the production of therapeutic antivenoms in Thailand. Toxicon. 2003;41(1):57-64. 
28. Ferreira Junior RS, Nascimento N, Couto R, Alves JB, Meira DA, Barraviera B. Laboratory evaluation of young ovines inoculated with natural or 60Co-irradiated Crotalus durissus terrificus venom during hyperimmunization process. J Venom Anim Toxins incl Trop Dis. 2006;12(4):620-31.

29. Oussedik-Oumehdi H, Laraba-Djebari F. Irradiated Cerastes cerastes venom as a novel tool for immunotherapy. Immunopharmacol Immunotoxicol. 2008;30(1):3752.

30. Jones RG, Corteling RL, Bhogal G, Landon J. A novel Fab based antivenom for the treatment of the mass bee attacks. Am J Trop Med Hyg. 1999;61(3):361-6.

31. Chippaux JP, Lang J, Amadi-Eddine S, Fagot P, Le Mener V. Short report: treatment of snake envenomation $s$ by anew polyvalent antivenom composed for highly purifyied $F\left(a b^{\prime}\right)_{2}$. Results of a clinical trial in northern Cameroon. Am J Trop Med Hyg. 1999;61(6):1017-8.

32. Fernandez I, Takeara HA, Mota I. Isolation of $\lg G(T)$ from hyperimmune horse anti-snake venom serum: its protective ability. Toxicon. 1991;29:1373-9.

33. Fernandez I, Takeara HA, Santos CR, Cormont F, Latinne D, Bazin H, Mota I. Neutralization of bothropic and crotalic venom toxic activities by $\lg G(\mathrm{~T})$ and $\lg \mathrm{Ga}$ subclases isolated from immune horse serum. Toxicon. 1997;35(6):931-6.

34. Fernández I, Lima EX, Takehara HA, Moura-da-Silva AM, Tanjoni I, Gutierrez JM. Horse IgG isotypes and cross-neutralization of two snake antivenoms produced in Brazil and Costa Rica. Toxicon. 2000;38(5):633-44.

35. Pope CG. Disaggregation of proteins by enzymes. Br J Exp Path. 1938;19:24551.

36. Pope CG. The action of proteolyitic enzymes on the antitoxin and proteins in inmune sera: I True digestion of the proteins. Br J Exp Path. 1939;20:132-49.

37. Pope CG. The action of proteolyitic enzymes on the antitoxin and proteins in inmune sera: II Heat denaturation after partial enzyme action. $\mathrm{Br} J$ Exp Path. 1939;20:201-12.

38. Sjostrom L, Al-Abdulla I, Rawat S, Smith D, Landon J. A comparation of ovine and equine antivenoms. Toxicon. 1994;32(4):427-33. 
39. Ariaratnam CA, Meyer WP, Perera G, Eddleston M, Kuleratne AM, Attapattu W, Sheriff R, Richards AM, Theakston RDG, Warrel DA. A new monospecific ovine Fab fragment antivenom for the treatment of envenoming by the Sri Lankan Russell's viper (Daboia russelli russelli): a preliminary dose-finding and pharmacokinetics study. Am J Trop Med Hyg. 1999;61(2):259-65.

40. Harrison RA, Hasson SS, Harmsen M, Laing GD, Conrath K, Theakston RDG. Neutralization of venom-induced haemorrhage by IgG from camels and llamas immunised with viper venom and also by endogenous, non-lgG components in camelid sera. Toxicon. 2006;47(3):364-8.

41. Herrera M, León G, Segura A, Meneses F, Lomonte B, Chippaux JP, Gutiérrez JM. Factors associated with adverse reactions induced by caprylic acid-fractionated whole IgG preparations: comparison between horse, sheep and camel IgGs. Toxicon. 2005;46(7):775-81.

42. Hamrock DJ. Adverse events associated with intravenous immunoglobulin therapy. Int Immunopharm. 2006;6(4):535-42.

43. Ferreira RN, Machado de Avila RA, Sanchez EF, Maria WS, Molina F, Granier C, Chávez-Olórtegui C. Antibodies against synthetic epitopes inhibit the enzymatic activity of mutalysin II, a metalloproteinase from bushmaster snake venom. Toxicon. 2006;48(8):1098-103.

44. Rafael A, Tanjoni I, Fernandes I, Moura-da-Silva AM, Furtado MF. An alternative method to access in vitro the hemorrhagic activity of snake venoms. Toxicon. 2008;51(4):479-87.

45. Sánchez EE, García C, Pérez JC, de La Zerda SJ. The detection of hemorrhagic proteins in snake venoms using monoclonal antibodies against Virginia opossum (Didelphis virginiana) serum. Toxicon. 1998;36(10):1451-9.

46. Stábeli RG, Magalhães LM, Selistre-de-Araujo HS, Oliveira EB. Antibodies to a fragment of the Bothrops moojenii-amino acid oxidase cross-react with snake venom components unrelated to the parent protein. Toxicon. 2005;46(3):308-17.

47. Tamarozzi MB, Soares SG, Marcussi S, Giglio JR, Barbosa JE. Expression of recombinant human antibody fragments capable of inhibiting the phospholipase and myotoxic activities of Bothrops jararacussu venom. Biochim Biophys Acta. 2006;1760(9):1450-7. 
48. Harrison RA, Wuster W, Theakston RGD. The conserved structure of snake venom toxins confers extensive immunological cross-reactivity to toxin-specific antibody. Toxicon. 2003;41(4):441-9.

49. Tanjoni I, Butera D, Bento L, Della-Casa M, Marques R, Takehara H, Gutiérrez JM, Fernández I, Moura da Silva A. Snake venom metalloproteinases: structure/function relationships studies using monoclonal antibodies. Toxicon. 2003;42(7):801-8.

50. Colombini M, Fernandes I, Cardoso DF, Moura-da-Silva AM. Lachesis muta muta venom: immunological differences compared with Bothrops atrox venom and importance of specific antivenom therapy. Toxicon. 2001;39(5):711-9.

51. Galán J, Sánchez E, Rodríguez-Acosta A, Pérez J. Neutralization of venoms from two Souther Pacific rattlesnakes (Crotalus helleri) with comercial antivenoms and endothermic animal sera. Toxicon. 2004;43(7):791-9.

52. Lizano S, Domont G, Perales J. Natural phospholipase A2 myotoxin inhibitor proteins from snakes, mammals and plants. Toxicon. 2003;42(8):963-77.

53. Peréz J, Sánchez E. Natural protease inhibitors to hemorrhagins in snake venoms and their potential use in medicine. Toxicon. 1999;37(5):703-28.

54. Nuñez V, Otero R, Barona J, Fonnegra R, Jiménez S, Osorio R, Quintana J, Díaz A. Inhibition of the toxic effects of Lachesis muta, Crotalus durissus cumanensis and Micrurus mipartitus snake venoms by plant extracts. Pharm Biol. 2004;42(1):49-54.

55. Mors W, Nacimento MC, Pereira BMR, Pereira NA. Plant natural products active against snake bite, the molecular approach. Phytochemistry. 2000;55(6):627-42.

56. Fortes-Dias C. Endogenous inhibitors of snake venom phospholipases A2 in the blood plasma of snakes. Toxicon. 2002;40(5):481-4.

57. Jurgilas P, Neves-Ferreira A, Domont G, Perales J. PO41, a snake venom metalloproteinase inhibitor isolated from Philander opossum serum. Toxicon. 2003;42(6):621-8.

58. Neves-Ferreira A, Cardinale N, Rocha S, Perales J, Domont G. Isolation and caracterization of DM40 and DM43, two snake venom metalloproteinase inhibitors from Didelphis marsupialis serum. Biochim Biophys Acta. 2000;1474(3):309-20.

59. Surza L, Rocha G, Lomonte B, Neves-Ferreira A, Trugilho M, Junqueira-deAzevedo I, Ho P, Domont G, Gutiérrez JM, Perales J. Functional analysis of DM64, an antimyotoxic protein with immunoglobulin-like structure from Didelphis marsupialis serum. Eur J Biochem. 2002;269:6052-62. 
60. Thwin M, Gopalakrishnakone P. Snake envenomation and protective natural endogenous proteins: a mini review of the recent developments (1991 - 1997). Toxicon. 1998;36(11):1471-82.

61. Abbas AK, Lichtman AH, Pober JS. Mecanismos efectores de la inmunidad humoral. In: Abbas AK, Lichtman AH, Pober JS. (editors). Inmunología celular y molecular. $4^{\text {th }}$. ed. Espana: Mc Graw Hill; 2002.

62. Abbas AK, Lichtman AH. Effector mechanisms of humoral immunity. In: Schmitt W, Hacker N, Ehlers J. (Editors). Cellular and molecular immunology. $5^{\text {th }}$. ed. Philadelphia: Elsevier Science Saunders; 2003.

63. García M, Monge M, León G, Lizano S, Segura E, Solano G, Rojas G, Gutiérrez JM.. Effect of preservatives on IgG aggregation, complement-activating effect and hypotensive activity of horse polyvalent anti-venom used in snakebite envenomation. Biologicals. 2002;30(2):143-51.

64. Otero R, Gutiérrez JM, Rojas G, Nuñez V, Díaz A, Miranda E, Uribe AF, Silva JF, Ospina JG, Medina Y, Toro MF, García ME, León G, García M, Lizano S, de La Torre J, Márquez J, Mena Y, González N, Arenas LC, Puzón A, Blanco N, Sierra A, Espinal M, Arboleda M, Jiménez JC, Ramírez P, Díaz M, Guzmán MC, Barros J, Henao S, Ramírez A, Macea U, Lozano R. A randomized, blinded clinical trial of two antivenoms, prepared by caprylic acid or ammonium sulphate fractionation of $\lg G$, in Bothrops and Porthidium snake bites Colombia: correlation between safety and biochemical characteristics of antivenoms. Toxicon. 1999;37(6):895-908.

65. Otero R, León G, Gutiérrez JM, Rojas G, Toro MF, Barona J, Rodríguez V, Díaz A, Nuñez V, Quintana JC, Ayala S, Mosquera D, Conrado L, Fernández D, Arroyo Y, Paniagua C, López M, Ospina C, Alzate C, Fernández J, Meza J, Silva J, Ramírez P, Fabra P, Ramírez E, Córdoba E, Arrieta A, Warrell DA, Theakston RDG. Efficacy and safety of two whole IgG polyvalent antivenoms, refined by caprylic acid fractionation with or without $\beta$-propiolactone, in the treatment of Bothrops asper bites in Colombia. Trans R Soc Trop Med Hyg. 2006;100(12):1173-82.

66. León G, Lomonte B, Gutiérrez JM. Anticomplementary activity of equine whole IgG antivenoms: comparison of three fractionation protocols. Toxicon. 2005;45(1):123-8.

67. Morais $\mathrm{V}$, Massaldi $\mathrm{H}$. Effect of pepsin digestion on the antivenom activity of equine immunoglobulins. Toxicon. 2005;46(8):876-82. 
68. Jones RG, Landon J. Enhanced pepsin digestion: a novel process for purifying antibody $\mathrm{f}(\mathrm{ab})_{2}$ fragments in high yield for serum. J Immunol Methods. 2002;263(12):57-74.

69. Jones RG, Landon J. A protocol for enhanced pepsin digestion a step by step method for obtained pure antibody fragments in high yield from serum. J Immunol Methods. 2003;275(1-2):239-50.

70. Rojas G, Espinoza M, Lomonte B, Gutiérrez JM. Effect of storage temperature on the stability of the liquid polyvalent antivenom produced in Costa Rica. Toxicon. 1990;28(1):101-5.

71. Silverstein AM. Clemens Freiherr von Pirquet: Explaining immune complex disease in 1906. Nat Immunol. 2000;1:453-5.

72. León G, Monge M, Rojas E, Lomonte B, Gutierrez JM. Comparison between IgG and $\mathrm{F}(\mathrm{ab})_{2}$ polyvalent antivenoms: neutralization of systemic effects induced by Bothrops asper venom in mice, extravasation of muscle tissue, and potential for induction of adverse reactions. Toxicon. 2001;39(6):793-801.

73. Silva de Freitas S, Machado RL, De Arruda EJ, Costapinto C, Alves Bueno S. Endotoxin removal from solutions of $\mathrm{F}\left(\mathrm{ab} \_\right) 2$ fragments of equine antibodies against snake venom using macroporous chitosan membrane. J Memb Sci. 2004;234(12):67-73.

74. Petsch D, Anspach FB. Endotoxin removal from protein solutions. J Biotechnol. 2000;76(2-3):97-119.

75. Brunn GJ, Platt JL. The etiology of sepsis: turned inside out. Trends Mol Med. 2006;12(1):10-6.

76. Erridge C, Bennett-Guerrero E, Poxton I. Structure and function of lipopolysaccharides. Microbes Infect. 2002;4(8):837-51.

77. Fang $\mathrm{H}$, Wei J, Yu Y. In vivo studies of endotoxin removal by lysine-cellulose adsorbents. Biomaterials. 2004;25(23):5433- 440.

78. Rangel-Frausto MS. Sepsis: still going strong. Arch Med Research. 2005;36(6):672-81.

79. Victor V, Rocha M, De La Fuente M. Immune cells: free radicals and antioxidants in sepsis. Int Inmunopharmacol. 2004;4(3):327-47.

80. Machado RL, De Arruda EJ, Santana CC, Bueno SMA. Evaluation of a chitosan membrane for removal of endotoxin from human $\lg G$ solutions. Process Biochem. 2006;41(11):2252-7. 
81. Massaldi $\mathrm{H}$, Morais V. Evolution of endotoxin contamination during production of a therapeutic serum. PDA J Pharm Sci Technol. 2007;61(5) :375-82.

82. Anspach FB. Endotoxin removal by affinity sorbents. J Biochem Biophys Methods. 2001;49(1-3):665-81.

83. Hirayama C, Sakata M. Chromatographic removal of endotoxin from protein solutions by polymer particles. J Chromatogr B Analyt Technol Biomed Life Sci. 2002;781(1-2):419-32.

84. Yamamoto K, Matsuda M, Hayama M, Sutagawa J, Tanaka S, Kohori F, Sakai K. Evaluation of the activity of endotoxin trapped by a hollow-fiber dialysis membrane. $\mathrm{J}$ Memb Sci. 2006;272(1-2):211-6.

85. Acconci C, Legallais C, Vijayalakshmi M, Alves S. Depyrogenation of snake antivenom serum solutions by hollow fiber-based pseudobioaffinity filtration. J Memb Sci. 2000;173(2):235-45.

86. Cheng A, Winkel K, Bawaskar HS, Bawaskar PH. Call for global snake-bite control and procurement funding. Lancet. 2001;357(9262):1132-3.

87. Laing GD, Renjifo JM, Ruiz F, Harrison RA, Nasidi A, Gutierrez JM, Rowley PD, Warrell DA, Theakston RDG. A new Pan African polyespecific antivenom developed in response to the antivenom crisis in Africa. Toxicon. 2003;42(1):35-41.

88. Laloo D, Theakston D, Warrell D. The African challenge. Lancet. 2002;359(9316):1527.

89. Theakston RDG, Warrell DA. Crisis of snake antivenom supply for Africa. Lancet. 2000;356(9247):2104. 